\title{
Decreased Bilirubin is Associated With Disease Activity of Primary Sjögren's Syndrome
}

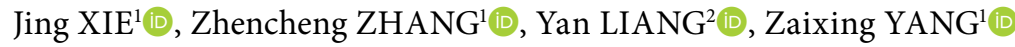 \\ ${ }^{1}$ Department of Laboratory Medicine,Huangyan Hospital of Wenzhou Medical University, Taizhou First People's Hospital, Taizhou, China \\ ${ }^{2}$ Department of Laboratory Diagnostics, Changzheng Hospital, Second Military Medical University, Shanghai, China
}

\begin{abstract}
Objectives: This study aims to determine the serum bilirubin levels in primary Sjögren's syndrome (pSS) patients and to explore clinical significance of bilirubin in pSS.

Patients and methods: Retrospective analysis of electronic medical records was performed in 97 pSS patients ( 12 males, 85 females; mean age $54 \pm 15$ years; range, 15 to 91 years) and 100 healthy controls ( 17 males, 83 females; mean age $51 \pm 14$ years; range, 25 to 75 years). Serum bilirubin and other variables were compared between pSS patients and healthy controls. The European League Against Rheumatism Sjögren's syndrome disease activity index (ESSDAI) was used to assess the disease activity of pSS, and ESSDAI $\geq 5$ was defined as moderate to high activity. The relationship between bilirubin and ESSDAI was analyzed by Spearman's correlation analysis and multivariable logistic regression.

Results: The median level of serum bilirubin was $9 \mu \mathrm{mol} / \mathrm{L}$ (interquartile range (IQR), 7-13 $\mu \mathrm{mol} / \mathrm{L}$ ) in pSS patients, much lower than healthy controls (median, IQR, 13, 10-18 $\mu \mathrm{mol} / \mathrm{L})(\mathrm{p}<0.001)$. It was positively correlated with age $(r=0.255, p=0.012)$, but negatively with immunoglobulin (Ig) A $(r=-0.314, p=0.003), \lg G(r=-0.265, p=0.015)$, erythrocyte sedimentation rate $(r=-0.309, p=0.002)$ and ESSDAl $(r=-0.342, p=0.001)$. Multivariate analysis revealed that increased bilirubin was independently associated with decreased risk of moderate to high disease activity (odds ratio, $95 \%$ confidence interval: 0.852, 0.730-0.955).
\end{abstract}

Conclusion: Serum bilirubin is decreased in pSS patients and may be a useful biomarker for reflecting pSS disease activity. Keywords: Bilirubin, disease activity, primary Sjögren's syndrome.

Primary Sjögren's syndrome (pSS) is a common systemic autoimmune disease of unknown cause, which predominantly affects females. ${ }^{1}$ Although pSS is characterized by autoimmune inflammation of exocrine glands leading to dryness of eyes and mouth, systemic manifestations vary between pSS patients and this heterogeneity is difficult to reflect in the underlying pathogenesis. To date, two indices for disease activity assessment in pSS have been validated by The European League Against Rheumatism (EULAR) task force, namely the EULAR Sjögren's syndrome disease activity index (ESSDAI) and EULAR Sjögren's syndrome patient-reported index (ESSPRI). ${ }^{2-5}$ The former is used for assessing systemic features and the latter for patients' symptoms. The sensitivity to disease change is better for ESSDAI than ESSPRI. However, both of the two indices have some limitations, including the subjectivity dependent on physician assessment or patients' response, and the difficulty of calculating ESSDAI or ESSPRI. Accordingly, it is necessary to search for more simple and objective biomarkers of pSS disease activity.

Received: May 22, 2019 Accepted: September 04, 2019 Published online: January 08, 2020

Correspondence: Zaixing Yang, MD. Department of Laboratory Medicine, Huangyan Hospital of Wenzhou Medical University, Taizhou First People's Hospital, 318020 Taizhou, China. Tel: +8657684016880 e-mail: yangzaixingdiyi@163.com 
Accumulating evidence suggested the occurrence of a prooxidant state in SS patients and involvement of oxidative stress in SS pathogenesis. $^{6-9}$ Bilirubin, a major breakdown product of heme catabolism, is a potent antioxidant with immunomodulatory and antiinflammatory activity at low physiological concentrations..$^{10,11}$ Moreover, bilirubin showed a stronger antioxidative function than many other antioxidants, including alpha-tocopherol, ascorbic acid, and catalase. . $^{12,13}$ Recently, decreased levels of serum bilirubin have been linked to some connective tissue diseases, including systemic lupus erythematosus (SLE), rheumatoid arthritis (RA), polymyositis (PM), the pathogenesis of which involves oxidative stress and inflammatory injury. ${ }^{14-19}$ However, to our knowledge, there has been no study investigating whether serum bilirubin is decreased in pSS patients. Therefore, in this study, we aimed to determine the serum bilirubin levels in pSS patients and to explore clinical significance of bilirubin in pSS.

\section{PATIENTS AND METHODS}

A total of 97 newly diagnosed patients with pSS (12 males, 85 females; mean age $54 \pm 15$ years; range, 15 to 91 years) in Changzheng Hospital were consecutively recruited in this study between January 2006 and December 2014. The diagnosis of pSS was based on the American-European Consensus Group criteria for pSS. ${ }^{20}$ Exclusion criteria were age $<18$ years, diagnosis of another autoimmune or inflammatory disease such as SLE, RA, PM/dermatomyositis, inflammatory bowel diseases, diabetes, cardiovascular diseases, etc., malignancies, liver diseases, hematology diseases or administration of blood transfusion in the past four months, or any pSS-related medical treatment. The healthy control group included 100 healthy individuals (17 males, 83 females; mean age $51 \pm 14$ years; range, 25 to 75 years) undergoing routine physical examinations in the hospital during the same period. They had no such significant underlying diseases as autoimmune disease, liver or renal disease, malignancies, hematologic diseases or diabetes.

Demographic, clinical and laboratory data were extracted from electronic medical records. ESSDAI of each pSS patient was calculated in accordance with 12 domains (i.e. constitutional, lymphadenopathy, glandular, articular, cutaneous, pulmonary, renal, muscular, peripheral nervous system, central nervous system, hematological, biological domains). ${ }^{2}$ Of note, blood samples were drawn and used for laboratory analysis after an overnight fasting of at least eight hours. The study protocol was approved by the Changzheng Hospital Ethics Committee. In accordance with the policy of our institution, written informed consents were not required, since this study using data from routine medical records had no influence on subsequent management of patients. The study was conducted in accordance with the principles of the Declaration of Helsinki.

\section{Statistical analysis}

Statistical analysis was performed using the PASW version 17.0 software (SPSS Inc., Chicago, IL, USA). Continuous variables were presented as mean \pm standard deviation for normal distribution and median and interquartile range (IQR) for non-normal distribution. Categorical variables were described as frequencies. Student t-test or Mann-Whitney $U$ test was used to compare continuous variables if appropriate. Categorical variables were compared by Chi square $\left(\chi^{2}\right)$ test. Spearman's correlation analysis was used for assessing the correlation between bilirubin and other continuous variables. Multivariate logistic regression was performed with inclusion of variables with $\mathrm{p}<0.05$ in the univariate analyses. Results were considered statistically significant when $p$ value was $<0.05$.

\section{RESULTS}

The clinical and laboratory characteristics of participants were shown in Table 1. The age and sex composition were comparable between pSS patients and healthy controls ( $>00.05$ ). White blood cell (WBC) count was significantly decreased in pSS patients. The median level of serum bilirubin was $9 \mu \mathrm{mol} / \mathrm{L}$ (IQR, 7-13 $\mu \mathrm{mol} / \mathrm{L}$ ) in $\mathrm{pSS}$ patients, much lower than healthy controls (median, IQR, 13, 10-18 $\mu \mathrm{mol} / \mathrm{L}) \quad(p<0.001)$ (Figure 1).

Mann-Whitney $\mathrm{U}$ test was used to analyze the association between serum bilirubin and categorical variables. The results showed that the 
Table 1. Clinical and laboratory characteristics of study subjects

\begin{tabular}{|c|c|c|c|c|c|c|c|c|c|c|}
\hline & \multicolumn{4}{|c|}{ pSS patients $(\mathrm{n}=97)$} & \multicolumn{4}{|c|}{ Healthy controls $(n=100)$} & \multirow[b]{2}{*}{$\begin{array}{l}\text { Reference } \\
\text { range }\end{array}$} & \multirow[b]{2}{*}{$p$} \\
\hline & $\mathrm{n}$ & Mean \pm SD & Median & Min-Max & $\mathrm{n}$ & Mean \pm SD & Median & Min-Max & & \\
\hline Age (year) & & $54 \pm 2$ & & & & & & & & 0.140 \\
\hline $\begin{array}{l}\text { Sex } \\
\quad \text { Male } \\
\text { Female }\end{array}$ & $\begin{array}{l}12 \\
85\end{array}$ & & & & $\begin{array}{l}17 \\
83\end{array}$ & $51 \pm 1$ & & & & 0.359 \\
\hline WBC count $\left(\times 10^{9} / \mathrm{L}\right)$ & & $5.3 \pm 2.5$ & & & & $6.1 \pm 1.2$ & & & $4-10$ & 0.003 \\
\hline $\operatorname{IgA}(\mathrm{g} / \mathrm{L})$ & & & 2.71 & $2.00-3.77$ & & & & & $0.82-4.53$ & \\
\hline $\operatorname{IgM}(\mathrm{g} / \mathrm{L})$ & & & 1.33 & $0.84-1.90$ & & & & & $0.46-3.04$ & \\
\hline $\operatorname{IgG}(\mathrm{g} / \mathrm{L})$ & & & 16.85 & $12.45-24.13$ & & & & & $7.51-15.60$ & \\
\hline $\mathrm{C} 3(\mathrm{~g} / \mathrm{L})$ & & & 0.83 & $0.70-1.02$ & & & & & $0.79-1.52$ & \\
\hline $\mathrm{C} 4(\mathrm{~g} / \mathrm{L})$ & & & 0.18 & $0.15-0.21$ & & & & & $0.16-0.38$ & \\
\hline $\mathrm{RF}(\mathrm{U} / \mathrm{ml})$ & & & 20 & $11-73$ & & & & & $0-20$ & \\
\hline $\mathrm{ESR}(\mathrm{mm} / \mathrm{h})$ & & & 38 & $16-74$ & & & & & $1-20$ & \\
\hline $\mathrm{CRP}(\mathrm{mg} / \mathrm{L})$ & & & 2.92 & $1.28-7.23$ & & & & & $0-10$ & \\
\hline ALT (U/L) & & & 16 & $11-24$ & & & 16 & $14-24$ & $0-40$ & 0.355 \\
\hline AST (U/L) & & & 21 & $17-28$ & & & 20 & $17-24$ & $0-35$ & 0.136 \\
\hline $\begin{array}{c}\text { ANA } \\
+ \\
-\end{array}$ & $\begin{array}{l}75 \\
22\end{array}$ & & & & & & & & & \\
\hline $\begin{array}{l}\text { Anti-SSA } \\
+ \\
-\end{array}$ & $\begin{array}{l}72 \\
25\end{array}$ & & & & & & & & & \\
\hline $\begin{array}{l}\text { Anti-SSB } \\
+ \\
-\end{array}$ & $\begin{array}{l}45 \\
52\end{array}$ & & & & & & & & & \\
\hline $\begin{array}{c}\text { ACA } \\
+ \\
-\end{array}$ & $\begin{array}{c}9 \\
88\end{array}$ & & & & & & & & & \\
\hline ESSDAI & & & 5 & $3-8$ & & & & & & \\
\hline
\end{tabular}

levels of serum bilirubin were significantly increased in pSS patients with anti-Sjögren's syndrome type B (anti-SSB) antibody compared with those without $(p=0.016)$, while they were not associated with sex, antinuclear antibodies, anti-centromere antibodies, and anti-Sjögren's syndrome type A antibody (Table 2). Spearman's correlation analysis was used for analyzing the correlation between bilirubin and continuous variables. The results indicated that serum bilirubin was positively correlated with age $(r=0.255, p=0.012)$, but negatively with immunoglobulin (Ig) A ( $\mathrm{r}=-0.314$, $p=0.003), \operatorname{IgG}(r=-0.265, p=0.015)$, erythrocyte sedimentation rate $(\mathrm{ESR})(\mathrm{r}=-0.309, \mathrm{p}=0.002)$ and ESSDAI ( $r=-0.342, p=0.001)$ (Table 3). There

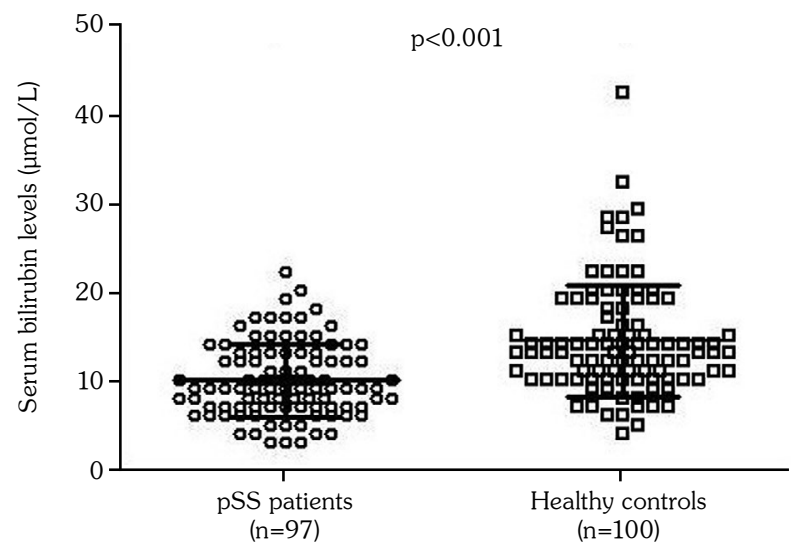

Figure 1. Serum bilirubin levels in pSS patients and healthy controls.

pSS: Primary Sjögren's syndrome. 
Table 2. Relationship between serum bilirubin and categorical variables

\begin{tabular}{|c|c|c|c|}
\hline & \multicolumn{2}{|c|}{ Bilirubin $(\mu \mathrm{mol} / \mathrm{L})$} & \multirow[b]{2}{*}{$p$} \\
\hline & Median & Min-Max & \\
\hline $\begin{array}{l}\text { Sex } \\
\quad \text { Male } \\
\text { Female }\end{array}$ & $\begin{array}{l}9.0 \\
9.0\end{array}$ & $\begin{array}{l}7.5-11.8 \\
7.0-13.0\end{array}$ & 0.895 \\
\hline $\begin{array}{l}\text { ANA } \\
\text { Positive } \\
\text { Negative }\end{array}$ & $\begin{array}{c}9.0 \\
12.5\end{array}$ & $\begin{array}{l}7.0-12.0 \\
8.8-15.0\end{array}$ & 0.122 \\
\hline $\begin{array}{c}\text { Anti-SSA } \\
\text { Positive } \\
\text { Negative }\end{array}$ & $\begin{array}{c}9.0 \\
10.0\end{array}$ & $\begin{array}{l}7.0-12.0 \\
7.5-15.0\end{array}$ & 0.137 \\
\hline $\begin{array}{c}\text { Anti-SSB } \\
\text { Positive } \\
\text { Negative }\end{array}$ & $\begin{array}{c}8.0 \\
10.0\end{array}$ & $\begin{array}{l}6.0-10.5 \\
8.0-14.0\end{array}$ & 0.016 \\
\hline $\begin{array}{l}\text { ACA } \\
\text { Positive } \\
\text { Negative }\end{array}$ & $\begin{array}{c}10.0 \\
9.0\end{array}$ & $\begin{array}{l}8.5-13.0 \\
7.0-13.0\end{array}$ & 0.485 \\
\hline
\end{tabular}

was no significant correlation between serum bilirubin and WBC count, IgM, complement components 3 and 4 , rheumatoid factor, C-reactive protein, alanine aminotransaminase and aspartate aminotransferase.

Since aforementioned univariate analysis showed that bilirubin was associated with anti-SSB antibody, age, IgA, IgG and ESR, we performed a multivariate logistic regression analysis including these indices to explore the independent association between bilirubin and disease activity. Inactivity or low activity was defined as ESSDAI $<5$ and moderate or high activity as ESSDAI $\geq 5$. The results indicated that serum bilirubin was independently associated
Table 3. Correlation between bilirubin and other continuous variables in $\mathrm{pSS}$ patients

\begin{tabular}{lcc}
\hline & \multicolumn{2}{c}{ Bilirubin } \\
\cline { 2 - 3 } Age & $\mathrm{r}$ & $\mathrm{p}$ \\
White blood cell count & 0.255 & 0.012 \\
Immunoglobulin A & -0.121 & 0.239 \\
Immunoglobulin M & -0.314 & 0.003 \\
Immunoglobulin G & 0.098 & 0.371 \\
Complement component 3 & -0.265 & 0.015 \\
Complement component 4 & 0.025 & 0.818 \\
Rheumatoid factor & 0.081 & 0.458 \\
Erythrocyte sedimentation rate & 0.007 & 0.957 \\
C-reactive protein & -0.309 & 0.002 \\
Alanine aminotransaminase & -0.190 & 0.069 \\
Aspartate aminotransferase & 0.107 & 0.297 \\
ESSDAI & 0.040 & 0.702 \\
\hline
\end{tabular}

pSS: Primary Sjögren's syndrome; ESSDAI: The European League Against Rheumatism Sjögren's syndrome disease activity index.

with disease activity (odds ratio, 95\% confidence interval: 0.852, 0.730-0.955) after adjusting for confounders (Table 4). Each increase per $\mu \mathrm{mol} / \mathrm{L}$ in serum bilirubin was associated with a significant $14.8 \%$ reduction in risk of moderate to high activity.

\section{DISCUSSION}

This is, to the best of our knowledge, the first study to investigate the level of serum bilirubin in pSS patients and the association of decreased bilirubin with pSS disease activity. In the present study, we found that the level of serum bilirubin was

Table 4. Multivariate logistic analysis of association with disease activity

\begin{tabular}{lccc}
\hline & \multicolumn{3}{c}{ ESSDAI $\geq 5$} \\
\cline { 2 - 3 } & OR & $95 \% \mathrm{CI}$ & $p$ \\
\hline Age & 1.005 & $0.959-1.054$ & 0.822 \\
Immunoglobulin A & 0.908 & $0.702-1.173$ & 0.459 \\
Immunoglobulin G & 1.057 & $0.945-1.181$ & 0.331 \\
Erythrocyte sedimentation rate & 1.035 & $1.006-1.064$ & 0.016 \\
Bilirubin & 0.852 & $0.730-0.955$ & 0.043 \\
Anti-Sjögren's syndrome type B antibody & 0.211 & $0.118-1.604$ & 0.435 \\
\hline ESSDAI: The European League Against Rheumatism Sjögren's syndrome disease activity index; & & & \\
OR: Odds ratio; CI: Confidence interval. & & & \\
\hline
\end{tabular}


decreased in pSS patients and that the decrease of bilirubin was closely associated with higher pSS disease activity, as measured by ESSDAI. Our findings indicated that serum bilirubin may be a potential index to estimate pSS disease activity.

The antioxidant property of bilirubin has been well recognized. ${ }^{10-13}$ Besides, bilirubin of physiological concentration also has immunomodulatory effects on antigen-presenting cells, effector cells and T helper 17 (Th17) cells, ultimately favoring the expansion of forkhead box protein $3+$ (FOXP3+) Tregs. ${ }^{21-25}$ A number of studies found that bilirubin is a protective factor and decreased in several inflammatory or autoimmune diseases such as atherosclerosis, SLE, RA, PM, and diabetic nephropathy. ${ }^{14-19,26,27}$ pSS is also a systemic autoimmune disease. It has been suggested that various immune effectors (such as Th1, Th17, T follicular helper, and $\mathrm{B}$ cells) may be involved in the pathogenesis of different phases in pSS. ${ }^{28}$ In addition, it has been proved that there is a prooxidant state in pSS patients and that oxidative stress may be an important factor in the pathogenesis of pSS..$^{6-9}$ Combined with the aforementioned biological activity of bilirubin and pathogenesis of pSS, our present findings of decreased bilirubin in pSS patients suggested that bilirubin may also play a protective role in pSS by antioxidation and immunoregulation, although the causality between the decrease of bilirubin and the development of pSS remains to be elucidated.

Another finding of this study is that serum bilirubin was inversely associated with disease activity and performed well in discriminating between low and moderate to high activity. This finding suggested that serum bilirubin may be a useful index for estimating pSS disease activity. Compared with ESSDAI and ESSPRI that were the only two indices validated by EULAR, serum bilirubin may be more simple and objective, and less likely to be affected by the experience of clinicians. Since the measurement of serum bilirubin is easy and inexpensive, it may be of clinical significance to measure serum bilirubin level in each pSS patient in routine tests. Furthermore, appropriate use of bilirubin may be a simple and cost-effective method for pSS treatment. Admittedly, how to use the bilirubin needs to be practiced in future studies.
Some limitations of this study should be addressed. Firstly, this is a cross-sectional study, in which the causal relationship between low bilirubin and pSS cannot be confirmed. Further prospective studies are needed to confirm the causality. Secondly, since this is a single-center study with small size, the results that may be biased should be interpreted in caution. Thirdly, due to the lack of more detailed clinical data, some factors such as smoking, drinking, and body mass index were not included in our multivariate analysis, which, possibly more or less, have some effects on our results.

In conclusion, the current study demonstrated that serum bilirubin was decreased in pSS patients and this decrease was independently associated with pSS disease activity. Bilirubin may be a simple, objective and useful biomarker for reflecting pSS disease activity.

\section{Declaration of conflicting interests}

The authors declared no conflicts of interest with respect to the authorship and/or publication of this article.

\section{Funding}

The authors received no financial support for the research and/or authorship of this article.

\section{REFERENCES}

1. Mariette X, Criswell LA. Primary Sjögren's Syndrome. N Engl J Med 2018;378:931-9.

2. Seror R, Ravaud P, Bowman SJ, Baron G, Tzioufas $\mathrm{A}$, Theander E, et al. EULAR Sjogren's syndrome disease activity index: development of a consensus systemic disease activity index for primary Sjogren's syndrome. Ann Rheum Dis 2010;69:1103-9.

3. Seror R, Ravaud P, Mariette X, Bootsma H, Theander $\mathrm{E}$, Hansen A, et al. EULAR Sjogren's Syndrome Patient Reported Index (ESSPRI): development of a consensus patient index for primary Sjogren's syndrome. Ann Rheum Dis 2011;70:968-72.

4. Seror R, Theander E, Brun JG, Ramos-Casals M, Valim V, Dörner $T$, et al. Validation of EULAR primary Sjögren's syndrome disease activity (ESSDAI) and patient indexes (ESSPRI). Ann Rheum Dis 2015;74:859-66.

5. Seror R, Mariette X, Bowman S, Baron G, Gottenberg $\mathrm{JE}$, Bootsma $\mathrm{H}$, et al. Accurate detection of changes in disease activity in primary Sjögren's syndrome by the European League Against Rheumatism Sjögren's Syndrome Disease Activity Index. Arthritis Care Res (Hoboken) 2010;62:551-8. 
6. Kurimoto C, Kawano S, Tsuji G, Hatachi S, Jikimoto T, Sugiyama D, et al. Thioredoxin may exert a protective effect against tissue damage caused by oxidative stress in salivary glands of patients with Sjögren's syndrome. J Rheumatol 2007;34:2035-43.

7. Norheim KB, Jonsson G, Harboe E, Hanasand M, Gøransson L, Omdal R. Oxidative stress, as measured by protein oxidation, is increased in primary Sjøgren's syndrome. Free Radic Res 2012;46:141-6.

8. Pagano G, Castello G, Pallardó FV. Sjøgren's syndrome-associated oxidative stress and mitochondrial dysfunction: prospects for chemoprevention trials. Free Radic Res 2013;47:71-3.

9. Wakamatsu TH, Dogru M, Matsumoto Y, Kojima T, Kaido M, Ibrahim OM, et al. Evaluation of lipid oxidative stress status in Sjögren syndrome patients. Invest Ophthalmol Vis Sci 2013;54:201-10.

10. Boon AC, Hawkins CL, Coombes JS, Wagner $\mathrm{KH}$, Bulmer AC. Bilirubin scavenges chloramines and inhibits myeloperoxidase-induced protein/lipid oxidation in physiologically relevant hyperbilirubinemic serum. Free Radic Biol Med 2015;86:259-68.

11. Basiglio CL, Toledo FD, Boaglio AC, Arriaga SM, Ochoa JE, Sánchez Pozzi EJ, et al. Physiological concentrations of unconjugated bilirubin prevent oxidative stress-induced hepatocanalicular dysfunction and cholestasis. Arch Toxicol 2014;88:501-14.

12. Stocker R, Yamamoto Y, McDonagh AF, Glazer AN, Ames BN. Bilirubin is an antioxidant of possible physiological importance. Science 1987;235:1043-6.

13. Wu TW, Carey $\mathrm{D}, \mathrm{Wu} \mathrm{J}$, Sugiyama $\mathrm{H}$. The cytoprotective effects of bilirubin and biliverdin on rat hepatocytes and human erythrocytes and the impact of albumin. Biochem Cell Biol 1991;69:828-34.

14. Yang Z, Liang Y, Li C, Xi W, Zhong R. Bilirubin levels in patients with systemic lupus erythematosus: increased or decreased? Rheumatol Int 2012;32:2423-30.

15. Vítek L, Muchová L, Jancová E, Pesicková S, Tegzová $\mathrm{D}$, Peterová $\mathrm{V}$, et al. Association of systemic lupus erythematosus with low serum bilirubin levels. Scand J Rheumatol 2010;39:480-4.

16. Peng YF, Wang JL, Pan GG. The correlation of serum bilirubin levels with disease activity in patients with rheumatoid arthritis. Clin Chim Acta 2017;469:187-90.

17. Juping D, Yuan Y, Shiyong C, Jun L, Xiuxiu Z, Haijian $Y$, et al. Serum bilirubin and the risk of rheumatoid arthritis. J Clin Lab Anal 2017;31.
18. Fischman D, Valluri A, Gorrepati VS, Murphy ME, Peters I, Cheriyath P. Bilirubin as a Protective Factor for Rheumatoid Arthritis: An NHANES Study of 2003 - 2006 Data. J Clin Med Res 2010;2:256-60.

19. Peng YF, Zhang L, Pan GG, Wei YS. A potential clinical usefulness of measuring serum bilirubin levels in patients with polymyositis. Eur Rev Med Pharmacol Sci 2016;20:631-5.

20. Vitali C, Bombardieri S, Jonsson R, Moutsopoulos HM, Alexander EL, Carsons SE, et al. Classification criteria for Sjögren's syndrome: a revised version of the European criteria proposed by the AmericanEuropean Consensus Group. Ann Rheum Dis 2002;61:554-8.

21. Liu Y, Li P, Lu J, Xiong W, Oger J, Tetzlaff W, et al. Bilirubin possesses powerful immunomodulatory activity and suppresses experimental autoimmune encephalomyelitis. J Immunol 2008;181:1887-97.

22. Wu J, Ma J, Fan ST, Schlitt HJ, Tsui TY. Bilirubin derived from heme degradation suppresses MHC class II expression in endothelial cells. Biochem Biophys Res Commun 2005;338:890-6.

23. Haga Y, Tempero MA, Kay D, Zetterman RK. Intracellular accumulation of unconjugated bilirubin inhibits phytohemagglutin-induced proliferation and interleukin-2 production of human lymphocytes. Dig Dis Sci 1996;41:1468-74.

24. Rocuts F, Zhang X, Yan J, Yue Y, Thomas M, Bach $\mathrm{FH}$, Bilirubin promotes de novo generation of $\mathrm{T}$ regulatory cells. Cell Transplant 2010;19:443-51.

25. Longhi MS, Vuerich M, Kalbasi A, Kenison JE, Yeste A, Csizmadia E, et al. Bilirubin suppresses Th17 immunity in colitis by upregulating CD39. JCI Insight. 2017;2.pii: 92791.

26. Akboga MK, Canpolat U, Sahinarslan A, Alsancak Y, Nurkoc S, Aras D, et al. Association of serum total bilirubin level with severity of coronary atherosclerosis is linked to systemic inflammation. Atherosclerosis 2015;240:110-4.

27. Li X, Zhang L, Chen H, Guo K, Yu H, Zhou J, et al. Relationship between serum bilirubin concentrations and diabetic nephropathy in Shanghai Han's patients with type 1 diabetes mellitus. BMC Nephrol 2017;18:114.

28. Psianou K, Panagoulias I, Papanastasiou AD, de Lastic AL, Rodi M, Spantidea PI, et al. Clinical and immunological parameters of Sjögren's syndrome. Autoimmun Rev 2018;17:1053-64. 